\title{
Screening of Nineteen Unrelated Families with Generalized Resistance to Thyroid Hormone for Known Point Mutations in the Thyroid Hormone Receptor $\beta$ Gene and the Detection of a New Mutation
}

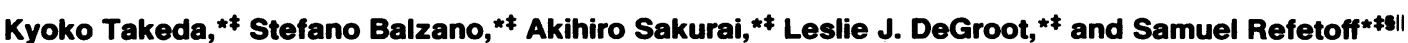

${ }^{*}$ Thyroid Study Unit, Departments of ${ }^{\ddagger}$ Medicine and $\$$ Pediatrics, and the $\| J$. P. Kennedy Jr. Mental Retardation Research Center, The University of Chicago, Chicago, Illinois 60637

\begin{abstract}
Generalized resistance to thyroid hormone (GRTH) is a syndrome characterized by impaired tissue responsiveness to thyroid hormone. Two distinct point mutations in the hormone binding domain of the thyroid hormone receptor (TR) $\beta$ have recently been identified in two unrelated families with GRTH. One, Mf, involves a replacement of the normal glycine-345 for arginine in exon 7 and another, Mh, replaces the normal proline-453 for histidine in exon 8 . To probe for the presence of the Mf and Mh defect in 19 unrelated families with GRTH, we applied separate polymerase chain reactions using allele-specific oligonucleotide primers containing the normal and each of the two mutant nucleotides at the 3'-position. A total of 24 affected subjects and 13 normal family members were studied. The mode of inheritance was dominant in 13 families, was unknown in 5 families, and was clearly recessive in 1 family in which only the consanguineous subjects were affected. Primers containing the substitutions specific for $M f$ and $M h$ amplified exons 7 and 8, respectively, only in affected members of each of the two index families. Primers containing the normal sequences amplified exons 7 and 8 of the TR $\beta$ gene in all subjects except affected members of one family. In this family with recessively inherited GRTH, neither exon could be amplified using any combinations of primers and DNA blot revealed absence of all coding exons. These results indicate a major deletion of the TR $\beta$ gene, including both DNA and hormone binding domains. Since heterozygous members of this family are not affected, the presence of a single normal allele is sufficient for normal function of the TR $\beta$. These data also support the hypothesis that in the dominant mode of GRTH inheritance the presence of an abnormal TR $\beta$ interferes with the function of the normal TR $\beta$. Distinct mutations are probably responsible for GRTH in unrelated families. (J. Clin. Invest. 1991. 87:496502.) Key words: allele-specific amplification - polymerase chain reaction
\end{abstract}

This paper was presented in part at the 72nd Annual Meeting of The Endocrine Society, 20-23 June 1990, in Atlanta, GA

Address reprint requests to Dr. Samuel Refetoff, Box 138, University of Chicago, 5841 South Maryland Avenue, Chicago, IL 60637.

Received for publication 7 June 1990 and in revised form 5 September 1990.

J. Clin. Invest.

(c) The American Society for Clinical Investigation, Inc. 0021-9738/91/02/0496/07 \$2.00

Volume 87, February 1991, 496-502

\section{Introduction}

Generalized resistance to thyroid hormone (GRTH) ${ }^{1}$ is a syndrome encompassing a heterogeneous group of conditions characterized by reduced responses of target tissues to a supply of thyroid hormone that under normal circumstances would be excessive (1-3). Usually the syndrome is first suspected when serum thyroid hormone levels are found to be elevated in association with nonsuppressed thyroid stimulating hormone (TSH). Clinical confirmation of the diagnosis requires the demonstration that full replacement doses of thyroid hormone fail to produce the expected suppressive effect on the secretion of TSH and fail to induce appropriate responses in peripheral tissues (4-7).

The heritable nature of the syndrome has been clearly demonstrated in 181 subjects with GRTH belonging to 47 families (8). (A complete list of references can be obtained from the senior author, S. Refetoff.) In the majority of families, inheritance appears to be autosomal dominant. However, recessive transmission was found in about $10 \%$ of families with proven or suspected consanguinity in four or five (9-12).

Although soon after the description of the syndrome it was postulated that this defect is most likely caused by an abnormal thyroid hormone receptor (4), this hypothesis could not be tested directly until the isolation of cDNAs that encode proteins with hormone-binding properties and functions typical of a thyroid hormone receptor (TR) (13-16). Two TR genes, designated $\alpha$ and $\beta$, have been identified in different animal species including man $(14,17,18)$ and have been mapped to human chromosomes 17 and 3 , respectively $(14,19)$. In addition to having a high structural similarity, these two genes generate isoforms by alternative splicing of the initial transcript $\left(\alpha_{1}, \alpha_{2}\right.$, $\left.\beta_{1}, \beta_{2}\right)(18,20,21)$ and probably also by synthesis from different translational start points (for example, the 55 and 52-kD $\beta_{1}$ products) (14). All TRs possess near their amino-terminal region a DNA-binding domain similar to that present in steroid hormone and retinoic acid receptors (22). A specific thyroid hormone-binding domain has been mapped to the carboxy terminus of the TR $\beta$ and $\operatorname{TR} \alpha_{1}$. The divergent amino-terminal sequence beyond amino acid 370 of the TR $\alpha_{2}$ isoform renders this TR $\alpha$ gene product devoid of hormone-binding properties (21).

1. Abbreviations used in this paper: GRTH, generalized resistance to thyroid hormone; $h$, human; $\mathrm{Mf}, \mathrm{Mh}$, mutations in TR $\beta$ associated with GRTH; PCR, polymerase chain reaction; TR, thyroid hormone receptor; TRE, thyroid response elements; TRH, thyrotropin-releasing hormone. 
Recent studies from our laboratory (23) and from the National Institutes of Health (24) have identified distinct point mutations in the human (h) TR $\beta$ gene of affected members from two unrelated families with GRTH. Both point mutations resulted in the substitution of single amino acids in the $\mathrm{T}_{3}$-binding domain of the hTR $\beta$ : a replacement of the normal glycine-345 with arginine in the family (Mf) studied in Chicago, and a replacement of the normal proline- 453 with histidine in the family $\mathrm{A}(\mathrm{Mh})$ studied at the National Institutes of Health (Fig. 1). (Substituted amino acids in family $\mathbf{M f}$ and $\mathbf{M h}$ were previously numbered glycine- 340 and proline- 448 , respectively $[23,24]$. The new numbers take into account the presence of five additional amino acids at the amino terminus as deduced from the corrected nucleotide sequence [25]). In both instances, the nucleotide substitution involved one of the two hTR $\beta$ alleles, compatible with the apparent dominant mode of GRTH inheritance in these two families. In vitro translation and transcription of the mutant hTR $\beta$-Mf yielded a product devoid of $\mathrm{T}_{3}$-binding property indicating that this mutation is responsible for the observed functional defect in affected members of this family (23).

In this study, we applied the technique of allele-specific amplification $(23,26,27)$ to probe for the presence of nucleotide substitutions identical to those found in Mf and Mh in 24 affected members from 19 unrelated families with GRTH, 13 unaffected relatives serving as controls. While the nucleotide substitutions could be identified by the allele-specific oligonucleotides in one of the two hTR $\beta$ alleles of affected members from families $\mathrm{Mf}$ and $\mathrm{Mh}$, identical nucleotide substitutions were not present in affected members of all other families studied. Failure to amplify exons 7 and 8 (termed $G$ and $H$, respectively, in reference 25 ) of TR $\beta$ containing the nucleotide substitutions $\mathrm{Mf}$ and $\mathrm{Mh}$, respectively, using both wild (normal) and mutant oligonucleotide pairs, lead to the recognition of deletion of the coding sequences of both hTR $\beta$ alleles in affected members of one family with recessively inherited GRTH. The heterozygous parents with a single hTR $\beta$ allele are clinically normal. These data indicate that a single normal allele is sufficient for normal function of the $\operatorname{hTR} \beta$ provided there is no interference by a nonfunction $\mathrm{hTR} \beta$.

\section{Methods}

Subjects. Data on all affected subjects and their normal relatives are summarized in Table I. All subjects with GRTH had reduced pituitary sensitivity to thyroid hormone in terms of suppression of their serum TSH in response to TRH during the administration of supraphysiologic doses of triiodothyronine $\left(\mathrm{T}_{3}\right)$ and/or thyroxine $\left(\mathrm{T}_{4}\right)$. Table I also provides information on the apparent mode of inheritance and gives the subjects identification code and references in which data from detailed clinical and laboratory studies can be found.

Allele-specific amplification of genomic DNAs. High molecular weight DNA was extracted from peripheral blood leukocyte or from cultured skin fibroblast nuclei (41) and was precipitated with ethanol. 100 pmol of the primer pairs $A B, A C, D E$, and DF (Table II) were annealed in separate reactions to 1-3 $\mu$ g genomic DNA and amplified for 25 or 30 cycles by the polymerase chain reaction (PCR) (42) according to the strategy depicted in Fig. 1. One cycle consisted of denaturation for $1 \mathrm{~min}$ at $94^{\circ} \mathrm{C}$, annealing for $2 \mathrm{~min}$ at 55 or $60^{\circ} \mathrm{C}$, and extension for $2 \mathrm{~min}$ at $67^{\circ} \mathrm{C}$. The resulting products were resolved by electrophoresis in a $2 \%$ GTG agarose gel (NuSieve; FMC BioProducts, Rockland, ME) and visualized with ultraviolet light after staining with ethidium bromide. If a pair of primers failed to generate a proper size fragment, the reaction was repeated at least twice. If a DNA sample could not be amplified with both normal and mutation-specific pairs of primers, the sample was reprecipitated with ethanol and the PCR reaction was repeated. Control positive and negative reactions were included.

DNA blotting. DNA was digested to completion with Eco RI (New England Biolabs, Beverly, MA), then subjected to $1.0 \%$ agarose gel electrophoresis, and following denaturation was transferred onto nitrocellulose paper (Southern blot). Hybridization was carried out under conditions previously described (43), using the hTR $\beta_{1}$ cDNA probe pheA4 (14) which is complementary to all exons (two 5'-noncoding and eight coding) (27). The probe covers 80 nucleotides (30\%) of the last coding exon (exon 8).

\section{Results}

A total of 292 PCR reactions were performed on 37 DNA samples belonging to 24 affected members from 19 unrelated families with GRTH and on 13 unaffected relatives. Fig. 2 shows the analysis of the products of exon 7 amplification with the primer pair specific for the wild type hTR $\beta$ (AB) and that specific for the Mf mutation (AC). Of 82 amplification reactions carried out with the primer pair specific for exon 7 of the wild type hTR $\beta$ and 75 amplifications with the Mf-specific primer pair, 16 and 68, respectively, failed to generate the expected DNA fragments. Excluding failure of amplification due to gene deletion (see below) there were a total of $7(8.5 \%)$ false negative reactions with the wild pair of primers (AB). They occurred at the first attempt of amplification in 3 of 34 DNA samples containing the hTR $\beta$ gene. In each instance, positive amplification

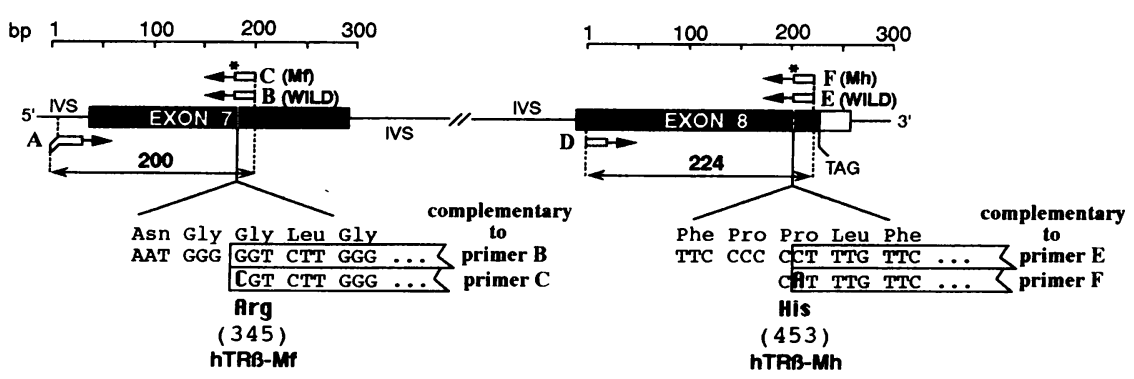

Figure 1. Mutations of hTR $\beta$ in GRTH and the strategy of screening for these mutations by allele-specific amplification of genomic DNA. The substitution of the wild $G$ for $C$ in exon 7 of hTR $\beta$-Mf results in the replacement of the normal Gly-345 for Arg in the $T_{3}$ binding domain of the TR $\beta$ giving rise to a receptor devoid of $\mathrm{T}_{3}$-binding activity (23). hTR $\beta$-Mh contains a substitution of the wild $\mathrm{C}$ for $\mathrm{A}$ in exon 8, resulting in the replacement of the normal Pro-454 for His (24). Coding regions (black areas) in exons (boxes),

intervening sequences $(I V S)$, and locations of the mutation sites and the termination codon $(T A G)$ are indicated. The primer pairs $\mathrm{AB}$ and DE amplify the normal alleles of hTR $\beta$ producing 200 and 224-bp fragments when annealed to exon 7 and exon 8 , respectively. Fragments of identical size are produced when primer pairs AC and DF are used with DNA samples containing the Mf and Mh mutations, respectively. Primers $\mathrm{C}$ and $\mathrm{F}$ are specific for the mutant alleles and contain at their $3^{\prime}$ terminal position the substituted nucleotide (asterisk). 
Table I. Summary of Hormone Data in Serum from All Patients with GRTH and Normal Subjects Investigated

\begin{tabular}{|c|c|c|c|c|c|c|c|c|c|}
\hline \multirow[t]{2}{*}{ Family } & \multirow[t]{2}{*}{ Subject* } & \multirow[t]{2}{*}{$\begin{array}{l}\text { Presumed } \\
\text { mode of } \\
\text { inheritance }\end{array}$} & \multicolumn{2}{|c|}{$\begin{array}{c}\text { Sex \& age } \\
\text { at diagnosis }\end{array}$} & \multirow{2}{*}{$\frac{\mathrm{T}_{4}}{n M}$} & \multirow{2}{*}{$\frac{\mathrm{T}_{3}}{n M}$} & \multirow[t]{2}{*}{$\begin{array}{c}\mathrm{FT}_{4} \text { or } \mathrm{FT}_{4} \mathrm{I} \\
\text { (\% of upper } \\
\text { normal limit) }\end{array}$} & \multirow{2}{*}{$\begin{array}{c}\text { TSH } \\
\text { mU/liter }\end{array}$} & \multirow[t]{2}{*}{$\begin{array}{c}\text { Reference and } \\
\text { subject identification" }\end{array}$} \\
\hline & & & & yrs & & & & & \\
\hline \multirow[t]{3}{*}{ I } & 1 & D & $\mathbf{M}$ & 6.5 & 324 & 5.82 & +139 & 3.2 & 6 (\#6), 23 (son), $\underline{28}$ (\#6) \\
\hline & 2 & & $\mathbf{M}$ & 39 & 227 & 3.69 & +107 & 1.4 & 6 (\#7), 23 (father), $\underline{28}$ (\#7) \\
\hline & 3 & & 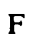 & 37 & 93 & 1.71 & -28 & 1.1 & 6 (normal), 23 (mother), 28 \\
\hline II & 1 & D & $\mathbf{M}$ & 8.5 & 232 & 5.34 & +80 & - & 5 (IV9), 12 (\#3), 24, 29 \\
\hline \multirow[t]{10}{*}{ III } & 1 & $\mathbf{R}$ & $\mathbf{M}$ & 12.5 & 279 & 4.76 & +105 & 5.5 & $4,9,28(\# 1), 30(\mathrm{mG}), 31(\# 2)$ \\
\hline & 2 & & $\mathrm{~F}$ & 10.5 & 338 & 18.59 & +195 & 5.8 & $4,9,28(\# 2), 30(v G), 31(\# 1)$ \\
\hline & 3 & & $\mathbf{M}$ & 1 & 286 & 3.61 & +148 & 1.6 & $4, \underline{9}, 32,33(\mathrm{maG})$ \\
\hline & 4 & & F & 37 & 107 & 1.81 & -33 & 4.4 & $\underline{9}(\mathrm{JG})$ \\
\hline & 5 & & $\mathbf{F}$ & 9.5 & 104 & 1.72 & -31 & 1.7 & $9(\mathrm{tG})$ \\
\hline & 6 & & $F$ & 17 & 104 & 2.21 & -32 & 3.1 & $\underline{9}(\mathrm{SM})$ \\
\hline & 7 & & $F$ & 3.5 & 131 & 2.38 & -18 & 1.7 & 9 (IG) \\
\hline & 8 & & $F$ & 4 & 133 & 2.72 & -10 & 1.3 & $\overline{N e w}$ \\
\hline & 9 & & $\mathbf{M}$ & 13 & 126 & 2.50 & -14 & 3.9 & New \\
\hline & 10 & & $\mathrm{~F}$ & $10.5^{\top}$ & 73 & 1.60 & -49 & 14.1 & $9(\mathrm{eG})$ \\
\hline \multirow[t]{4}{*}{ IV } & 1 & D & $\mathbf{F}$ & 0.2 & 192 & 4.30 & +39 & 15.5 & $\overline{N e w}$ \\
\hline & 2 & & $\mathbf{M}$ & 2.5 & 205 & 3.24 & +55 & 5.0 & $6(\# 8)$ \\
\hline & 3 & & $F$ & 29 & 143 & 2.49 & +10 & 1.2 & New \\
\hline & 4 & & $\mathbf{M}$ & 37 & 118 & 2.11 & -9 & 3.1 & New \\
\hline \multirow[t]{2}{*}{$\mathbf{v}$} & 1 & D & $\mathbf{M}$ & 25 & 265 & 4.38 & +89 & 2.7 & $34(\# 3)$ \\
\hline & 2 & & $\mathrm{~F}$ & 25 & 161 & 2.49 & -6 & 1.2 & 28 \\
\hline VI & 1 & D & $F$ & 25 & 270 & 3.99 & +261 & 7.0 & 35 (propositus) \\
\hline VII & 1 & D & $\mathbf{M}$ & 0.5 & 284 & 5.13 & +88 & 7.6 & $\underline{10}, 28,31(3)$ \\
\hline VIII & 1 & D & $\mathbf{F}$ & 7 & 275 & 4.93 & +40 & 1.3 & $\overline{36}(\mathrm{HM})$ \\
\hline IX & 1 & D & $\mathrm{F}$ & 11 & 192 & 4.02 & +62 & 260 & $6(\# 1), 28,31(\# 4), 37$ (LM) \\
\hline $\mathbf{X}$ & 1 & $\mathrm{nk}^{* *}$ & $\mathbf{M}$ & 9 & 224 & 4.96 & +67 & 3.3 & $6(\# 2), \underline{31}(\# 6)$ \\
\hline XI & 1 & D & $\mathrm{F}$ & 74 & 288 & 3.86 & +57 & 3.0 & $31(\# 5), \underline{38}(\# 1)$ \\
\hline XII & 1 & D & $F$ & 6 & 245 & 4.30 & +105 & 5.9 & $\underline{39}, 40(\overline{\mathrm{VT}})$ \\
\hline XIII & 1 & $\mathbf{n k}^{\ddagger}$ & $\mathbf{M}$ & 8.7 & 286 & 5.02 & +149 & 4.4 & $6(\# 9)$ \\
\hline XIV & 1 & $n^{88}$ & $\mathbf{M}$ & 0.7 & 230 & 4.22 & +40 & 18.5 & 7 (new) \\
\hline XV & 1 & $\mathrm{D}$ & $\mathrm{F}$ & 5 & 256 & 4.02 & +83 & 3.1 & New \\
\hline XVI & $\mathbf{1}$ & $\mathbf{n k}^{\prime \prime \prime I I}$ & $\mathbf{F}$ & 4.8 & 237 & 5.13 & +100 & 2.0 & New \\
\hline \multirow[t]{2}{*}{ XVII } & 1 & $\mathrm{D}$ & $\mathrm{F}$ & 31 & 228 & 3.44 & +59 & 1.3 & New \\
\hline & 2 & & $\mathrm{~F}$ & 40 & 122 & 1.94 & -34 & 1.7 & New \\
\hline XVIII & 1 & $n k^{n}$ & $\mathrm{~F}$ & 31 & 360 & 3.15 & +171 & 4.2 & New \\
\hline \multirow[t]{5}{*}{ XIX } & $\mathbf{1}$ & D & $\mathbf{M}$ & 28 & 225 & 4.44 & +75 & 3.0 & New \\
\hline & 2 & & $F$ & 4 & 120 & 3.19 & -19 & 2.2 & New \\
\hline & 3 & & $\mathbf{M}$ & 3 & 133 & 3.21 & -10 & 1.6 & New \\
\hline & Normal & & & & & & & & \\
\hline & Control & - & $\mathbf{M}$ & 29 & 113 & 1.90 & -5 & 0.9 & \\
\hline \multicolumn{2}{|c|}{ Normal range } & & & & $64-154$ & $1.38-2.84^{* * * *}$ & $-43-0$ & $0.5-4.0$ & \\
\hline
\end{tabular}

$\mathrm{FT}_{4}$, free $\mathrm{T}_{4} ; \mathrm{FT}_{4} \mathrm{I}$, free $\mathrm{T}_{4}$ index. ${ }^{*}$ Affected in bold numbers. ${ }^{\ddagger} \mathrm{D}$, dominant; $\mathrm{R}$, recessive; nk, not known. ${ }^{8}+$, above, and -, below, upper limit of normal. "Reference first describing affected subjects is underlined. 'Values from blood sample obtained at age 32, at which time she developed hypothyroidism due to autoimmune thyroid disease. ${ }^{* *}$ Adopted. ${ }^{\ddagger \ddagger}$ Affected identical twin but both parents normal; possible new mutation. Both parents normal. "III Recessive or new mutation since two sibs, both parents, paternal and maternal grandparents, and paternal aunt and cousin are normal. "Family not studied. *** In prepubertal children, upper limit of normal is $3.22 \mathrm{nM}$.

was observed on a second trial. A DNA fragment of the appropriate size was generated with the Mf-mutation pair of primers only when DNA from affected members of family Mf was used as template.

Fig. 3 presents the analysis of the products of exon 8 amplification with the pair of primers specific for the wild type hTR $\beta$ (DE) and that specific for the Mh mutation (DF). Of 70 ampli- fication reactions carried out with the primer pair specific for exon 8 of the wild type hTR $\beta$ and 65 amplifications with the Mh-specific primer pair, 12 and 63, respectively, failed to generate the expected DNA fragments. Again, excluding failures of amplification due to gene deletion, there were a total of 3 (4.3\%) false negative reactions, of which only one occurred on the first attempt of amplification. Also, the Mh-mutant pair of 
Table II. Sequences and Locations of Oligonucleotide Primers

\begin{tabular}{|c|c|c|c|}
\hline Primer & Sequence & Orientation & Location \\
\hline A & $5^{\prime}-G G A A T T C$ tgctgacatgaactggttct- $3^{\prime}$ & sense & $7-27$ nucleotides $5^{\prime}$ from exon 7 \\
\hline B & 5'-TCTGACACCACCCCAAGACC-3' & antisense & nucleotides $148-168$ of exon 7 \\
\hline C & 5'-TCTGACACCACCCCAAGACG-3' & antisense & nucleotides $148-168$ of exon 7 \\
\hline D & 5'-GGCTTGCCTGTGTTGAGAGA-3' & sense & nucleotides $10-30$ of exon 8 \\
\hline $\mathrm{E}$ & 5'-GAACACTTCCAAGAACAAAG-3' & antisense & nucleotides $214-234$ of exon 8 \\
\hline $\mathrm{F}$ & 5'-GAACACTTCCAAGAACAAAT-3' & antisense & nucleotides $214-234$ of exon 8 \\
\hline
\end{tabular}

Capital letters in italic, adapter sequence; lower case letters, intronic sequence; capital letters, exonic sequences; capital and bold letters, mutant nucleotides ( $G$ in primer $\mathrm{C}$, Mf mutant; $\mathrm{T}$ in primer $\mathrm{F}, \mathrm{Mh}$ mutant).

primers generated a DNA fragment of the proper size only when used to amplify DNA derived from an affected member of the Mh family. This result was observed in two separate amplification reactions.

Amplification of exons 7 and 8 of the $h T R \beta$ failed using both wild type and the two mutation-specific primers when DNA samples from affected members of consanguineous family III (see Table I) were used as template (Fig. 4). This occurred on three separate trials and with DNA obtained from leukocytes and from fibroblasts of three affected members of the family (III-1, III-2, and III-3). In contrast, the wild type primers $\mathrm{AB}$ and DE generated DNA fragments appropriate for exon 7 and exon 8, respectively, when annealed to DNA obtained from the unaffected mother (III-4), four sibs (III-5, III-6, III-7, and III-10), a niece (III-8), and a nephew (III-9). This was observed on the first attempt of amplification and none of these samples could be amplified using the two mutation-specific primers. DNA from the affected members of this family also failed to sustain the PCR with primers specific for intronic sequences flanking each coding exon 3 through 6 , while the same primers generated DNA fragments when using control DNA samples from healthy individuals (data not shown).

To determine the extent of hTR $\beta$ gene deletion in family III, genomic DNA was digested with Eco RI and, after electrophoresis on $1.0 \%$ agarose gel, was DNA blotted and hybridized with a hTR $\beta$ cDNA probe. As shown in Fig. 5, compared with the wild type control DNA sample, the affected subject, III-3, demonstrated only two bands: one corresponding to the larger noncoding exon of the hTR $\beta$ gene (exon 00 , not visible in the photograph of the gel) and another band, most likely representing the second noncoding exon (exon 0 ).

\section{Discussion}

This study failed to identify, in 19 unrelated families with GRTH, mutations identical to those recently described in two families $(23,24)$ also included in the analysis. This is not surprising considering available data on mutations in other in-
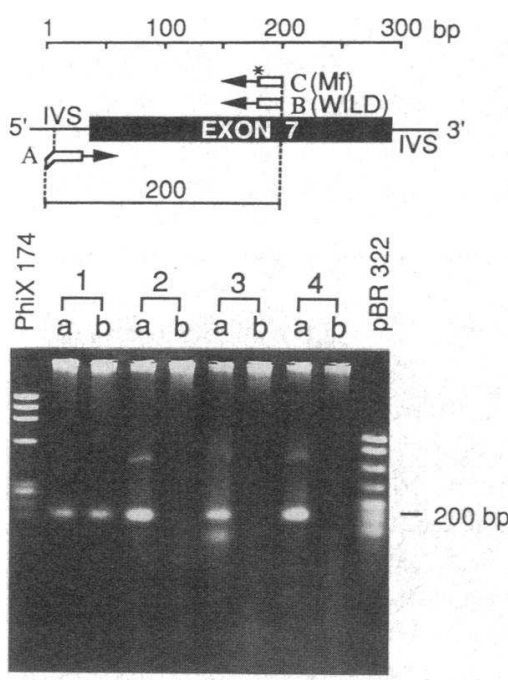

Figure 2. Detection of normal and the Mf mutant $h T R \beta$ allele in genomic DNA by allelespecific amplification. The strategy of amplification is diagramed at the top of the figure. DNA samples annealed with the primer pair $\mathrm{AB}$ (lanes $a$ ) amplify the normal allele and those annealing with the primer pair AC (lanes $b$ ), the mutant allele $(M f)$. For details see legend to Fig. 1. DNA samples $1-4$ are: (1) affected subject (I-2)

heterozygous for the Mf mutation; (2) affected subject (II-1) heterozygous for the Mh mutation; (3) affected subject (IV-1); and (4) normal subject (IV-4). PhiX174 and pBR 322, digested with Hae III and Msp I, respectively, serve as size markers. Note that while the pair of primers specific for exon 7 of the wild type hTR $\beta$ amplified all DNA samples, primer $C$, complementary to the Mf sequence, amplified only the DNA from the subject carrying this mutation. Weaker and more diffuse bands, bigger and smaller than $200 \mathrm{bp}$, are PCR artifacts.

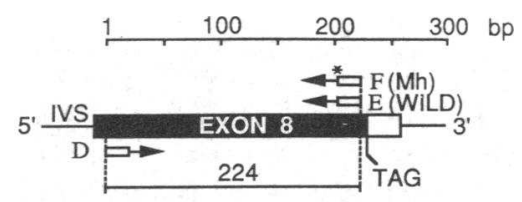

Figure 3. Detection of normal and the Mh mutant $h$ TR $\beta$ allele in genomic DNA by allelespecific amplification.

The strategy of amplification is

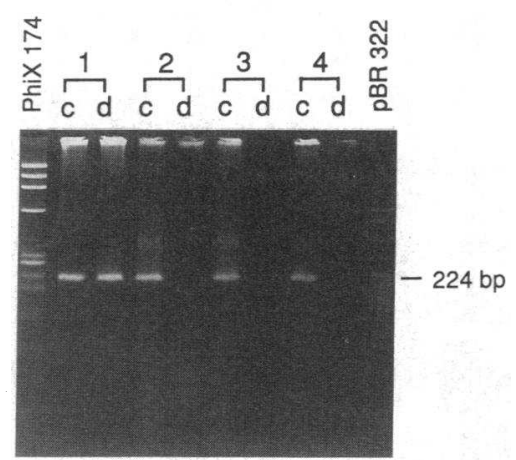

diagramed on top of the figure. DNA samples annealed with the primer pair DE (lanes $c$ ) amplify the normal allele and those annealing with the primer pair DF (lanes $d$ ), the mutant allele $(M h)$. For details see legend to Fig. 1. DNA samples $1-4$ are: (I) affected subject (II-1) heterozygous for the Mh mutation; (2) affected subject (I-2) heterozygous for the Mf mutation; (3) affected subject (IV-1); and (4) normal subject (IV-4). PhiX174 and pBR 322, digested with Hae III and Msp I, respectively, serve as size markers. Note that while the pair of primers specific for exon 8 of the wild type hTR $\beta$ amplified all DNA samples, primer F, complementary to the Mh sequence, amplified only the DNA from the subject carrying this mutation. Weaker and more diffuse bands, bigger than $224 \mathrm{bp}$, are PCR artifacts. 
herited diseases resulting from the malfunction of a single protein $(44,45)$. Accordingly, although the method of allele-specific amplification has a high detection specificity (no false positive results and only 3-9\% false negative on the first trial), it has no practical value in mass-screening for GRTH. Indirect diagnosis based on measurements of $\mathrm{T}_{4}$ and TSH is currently the method of choice for the early diagnosis of this condition (46). On the other hand, when the precise defect at the gene level is known, allele-specific amplification is suitable for the prenatal identification of affected members in individual families.

Most surprising was the finding of complete deletion of the coding sequences of hTR $\beta$ gene in one of the 19 families with GRTH studied (family III). The absence of both alleles in affected members is compatible with the predicted recessive mode of inheritance based on pedigree analysis of this consanguineous family (9). The most significant conclusion derived from this observation is that the hTR $\beta$ appears not to be essential for survival. It is, thus, logical to speculate that the $h T R \alpha$ is functional and may partially substitute for the $h \operatorname{TR} \beta$, being expressed in all tissues so far examined $(47,48)$. Although affected members of this family have severe hyposensitivity to thyroid hormone and exhibit, in addition, deaf-mutism, epiphyseal dysgenesis, and other minor somatic abnormalities, the defect is adequately compensated in most tissues by maintaining high circulating levels of the hormone $(4,9)$.

An unusual feature of family III is the previously observed paradoxical increase of serum TSH concentration in response to thyrotropin-releasing hormone (TRH) during the administration of supraphysiologic doses of $T_{3}(33)$. This unique phenomenon was formerly attributed to the severe degree of their hormone resistance, akin to the effect of small doses of thyroid hormone given to hypothyroid subjects (49). Based on the finding of absent $\mathrm{hTR} \beta$ in these homozygous individuals, a different explanation can be now offered for the paradoxical increase in TSH. In the rat pituitary, thyroid hormone normally downregulates the $\operatorname{TR} \alpha_{1}$ and $\alpha_{2}$ as well as $\operatorname{TR} \beta_{2}$ by $20-40 \%$ but upregulates the expression of the $\operatorname{TR} \beta_{1}$ by $340 \%$ (48). If thyroid hormone exerts the same control on the expression of the TR $\alpha$ and $\beta$ genes of human pituitary, then the observed increase in TSH response, rather than downregulation by $T_{3}$ in affected patients from family III, may be the result of the net reduction of $\operatorname{TR} \alpha$ unopposed by the normal increase in $\operatorname{TR} \beta_{1}$.

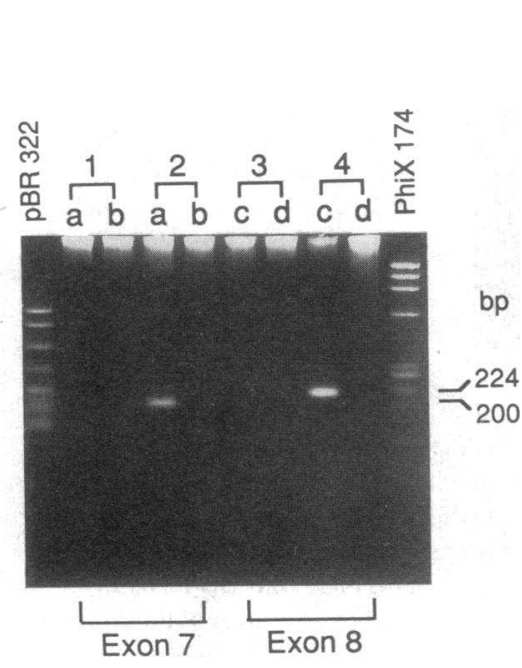

Figure 4. Detection of partial hTR $\beta$ gene deletion in genomic DNA by allele-specific amplification. The strategies of amplification are diagramed on top of Figs. 2 and 3. For details see legend to these figures and Fig. 1. DNA samples are: (I) and (3) affected subject III-3; and (2) and (4) normal subject III-5. Note the failure of the four primer pairs to amplify DNA of an affected subject, III-3.

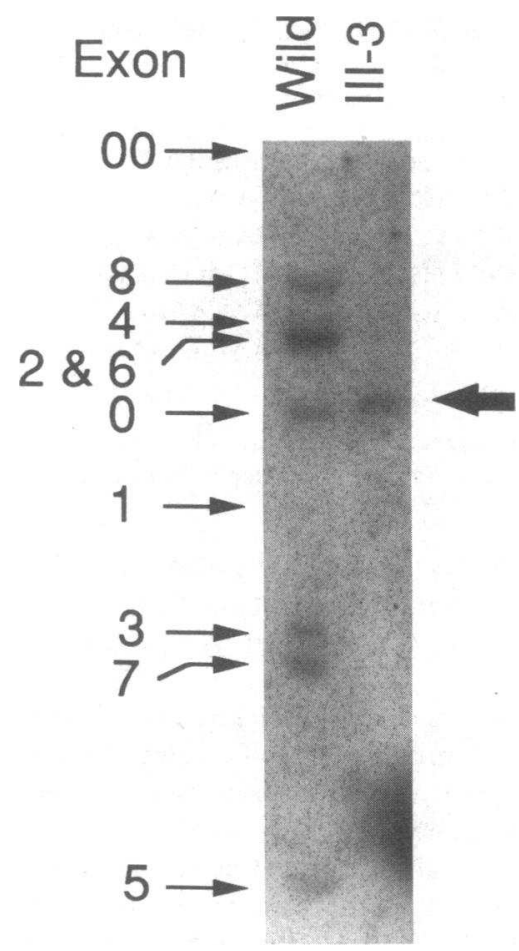

Figure 5. Southern analysis of $h \operatorname{TR} \beta$ of a normal subject and that of an affected subject from family III. DNA was digested with Eco RI and hybridized with a hTR $\beta_{1}$ cDNA covering the two noncoding and the eight coding exons. All intervening sequences but not exons of the $\mathrm{hTR} \beta$ contain at least one Eco RI restriction site producing bands corresponding to each exon (27) indicated by the arrows. Too weak to reproduce photographically were the bands corresponding to exon 00 (present in both wild and III-3 DNA samples) and exon 1 (present only in the wild DNA sample). The DNA segment generated by subject III-3 (thick arrow) most likely represents the second noncoding exon (exon 0 ), downstream of which the hTR $\beta$ has been deleted.

Previous attempts to demonstrate abnormalities in $\mathrm{T}_{3}$-binding affinity or capacity of TR extracted from cell nuclei have been in general disappointing. Indeed, in studies carried out in 32 patients with GRTH belonging to 21 unrelated families, no abnormalities were found in $60 \%$ of cases using TR extracted from circulating mononuclear cells and in $50 \%$ using cultured fibroblasts (3). Yet, a 10-fold decrease in the $T_{3}$-affinity was observed in extracts from lymphocyte nuclei belonging to subject III-3 in this study (32). This finding, formerly interpreted as the presence of a mutant TR with reduced affinity for $T_{3}$, is in apparent conflict with the current finding of total absence of $\mathrm{hTR} \beta$ in the same individual. However, recent studies by Schueler et al. (50) showing a fivefold reduced rat TR $\alpha$ affinity for $T_{3}$ as compared with rat $\operatorname{TR} \beta$ provide an explanation for the seeming discrepancy. Complete absence of the hTR $\beta$ very likely uncovered the normal hTR $\alpha$ forms expressed as the sole TRs in these individuals, accounting for the observed reduced affinity of $T_{3}$ binding to total nuclear extracts.

Finally, the lack of clinical and laboratory manifestations in the obligate heterozygous subjects from family III deserves a comment in view of the fact that in the majority of patients with GRTH, the condition is fully manifested in the heterozygous state $(23,24)$. Fig. 6 provides a pictorial representation of current information on the functional interaction between thyroid hormone, its receptor, and thyroid response elements (TRE) as well as hypothetical models explaining the mechanism of action of mutant receptors. One possible explanation for the dominant expression of GRTH is that a mutant TR competes with the normal TR for its interaction with TREs. However, a simple competition is unlikely to have a dominant effect considering the excess of functioning TRs (51). A more plausible explanation is derived from recent work which 
a

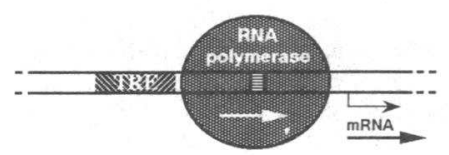

b

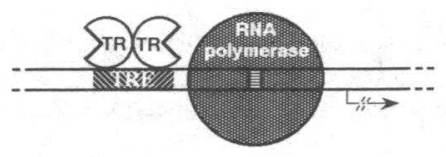

C

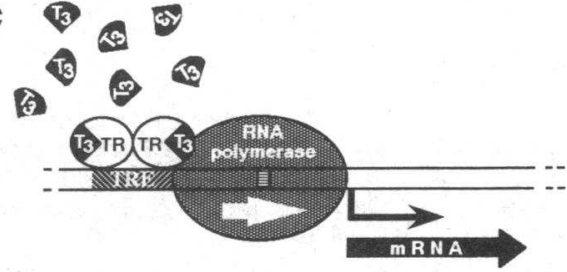

Effect of Mutant TR

A

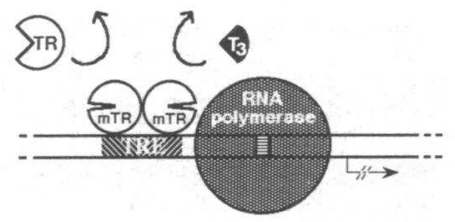

B

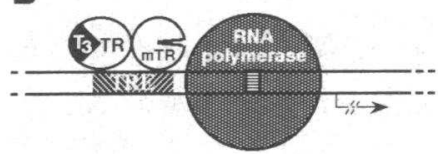

$$
\text { SR. Thyroid receptor T3R Activated TR ST Mutant thyroid }
$$

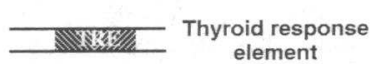

Figure 6. Schematic representation of the functional interaction of thyroid hormone $\left(\mathrm{T}_{3}\right)$, its receptor and TRE, and models for interaction with a mutant receptor in heterozygous subjects. (a) Basal expression of a thyroid responsive gene; $(b)$ its inactivation by binding of inactive TR to TRE; and $(c)$ its activation by changes in the steric configuration of the TR produced by interaction with the hormone $\left(T_{3}\right)$. Dominant negative models of thyroid hormone resistance produced by the mutant receptor include: $(A)$ competition of the mTR with TR for TRE and inhibition of responsive gene expression by interaction with TRE; $(B)$ formation of inactive heterodimers reducing the functional capacity of both normal TR and $\mathrm{T}_{3}$.

showed that, in the absence of hormone, TRs can exert an inhibitory effect on genes whose expression is activated by TR in the presence of hormone $(16,52)$. Accordingly, the heterozygous expression of a mutant TR that is defective in its $T_{3}$-binding domain but retains the DNA-binding domain may not only compete with the normal TR by binding to TREs but also act in a dominant-negative fashion. Another reason for the observed hormone refractoriness when a single normal TR allele is expressed along with a mutant allele but not alone is based on data indicating that transactivation requires the formation of TR dimers (53). The formation of heterodimers between normal and functionally inactive mutant TRs would further diminish the activity of the expressed normal TR even if the latter were associated with the hormone. This would further reduce the amount of normal and potentially functional TR-T complexes, wasting the hormone. As a result, higher concentrations of the hormone would be required to produce sufficient amount of hormone-saturated TR homodimers as actually observed in patients with GRTH. Formation of heterodimers between mutant and normal homologous or heterologous TRs and their isoforms possessing tissue-specific differential regulation can easily account for the observed heterogeneity of clinical manifestations among families harboring TR defects. Clearly in the heterozygous state there are advantages in having gene deletion rather than expression of a functionally defective mutant TR.

\section{Acknowledgments}

We thank the following individuals for the referral of patients or provision of material in the form of whole blood or skin fibroblasts: Dr. Nives Dumbovic (families I and X), Dr. Charles Eil (family II), Dr. Gregory B. Pehling (family V), Dr. Phillip DeNayer and Dr. J. V. Vandalem (family VI), Dr. Paul B. Kaplowitz (family VII), Dr. Alan Chait (family VIII), Dr. Randolph Seed (family IX), Dr. Jacobo Wortsman (family XI), Dr. I. A. Hughes (family XII), Dr. Barry H. Rich (family XIII), Dr. Desmond Schatz and Dr. William E. Winter (family XV), Dr. Deborah V. Edidin (family XVI), Dr. Claudio Marcocchi (family XVII), Dr. Catherine M. Edwards and Dr. P. W. Stacpoole (family XVIII), and Dr. Corbin P. Roudebush (family XIX). Thanks are also due to Dr. Cary Weinberger for provision of the hTR $\beta$ cDNA probe, to Jytta Hansen for the culture of fibroblasts, to Dr. Graeme I. Bell for advice on the planning and execution of experiments, and to Mrs. Yolanda W. Richmond for preparation of the manuscript.

This work was supported in part by grants from the National Institutes of Health (DK-15,070, DK-13,377, and DK-00,055), and from the March of Dimes Birth Defects Foundation.

\section{References}

1. Lamberg, B.-A., and K. Liewendahl. 1980. Thyroid hormone resistance. Ann. Clin. Res. 12:243-253.

2. Weintraub, B. D., M. C. Gershengorn, I. A. Kourides, and H. Fein. 1981. Inappropriate secretion of thyroid stimulating hormone. Ann. Intern. Med. 95:339-351.

3. Refetoff, S. 1989. The syndrome of generalized resistance to thyroid hormone (GRTH). Endocr. Res. 15:717-743.

4. Refetoff, S., L. J. DeGroot, B. Benard, and L. T. DeWind. 1972. Studies of a sibship with apparent hereditary resistance to the intracellular action of thyroid hormone. Metab. Clin. Exp. 21:723-756.

5. Magner, J. A., P. Petrick, M. M. Menezes-Ferreira, M. Stelling, and B. D. Weintraub. 1986. Familial generalized resistance to thyroid hormones: report of three kindreds and correlation of patterns of affected tissues with the binding of ${ }^{125}$ I] triiodothyronine to fibroblast nuclei. J. Endocrinol. Invest. 9:459-470.

6. Sarne, D. H., S. Refetoff, R. L. Rosenfield, and J. P. Farriaux. 1988. Sexhormone binding globulin in the diagnosis of peripheral tissue resistance to thyroid hormone: the value of changes following short-term triiodothyronine administration. J. Clin. Endocrinol \& Metab. 66:740-746.

7. Sarne, D. H., S. Sobieszczyk, K. B. Ain, and S. Refetoff. 1990. Serum thyrotropin and prolactin in the syndrome of generalized resistance to thyroid hormone: responses to thyrotropin-releasing hormone stimulation and triiodothyronine suppression. J. Clin. Endocrinol. \& Metab. 70:1305-1311.

8. Refetoff, S. 1990. Resistance to thyroid hormone revisited. Thyroid Today. 13:1-11. 
9. Refetoff, S., L. T. DeWind, and L. J. DeGroot. 1967. Familial syndrome combining deaf-mutism, stippled epiphyses, goiter, and abnormally high PBI: possible target organ refractoriness to thyroid hormone. J. Clin. Endocrinol. \& Metab. 27:279-294.

10. Kaplowitz, P. B., A. J. D'Ercole, and R. D. Utiger. 1981. Peripheral resistance to thyroid hormone in an infant. J. Clin. Endocrinol. \& Metab. 53:958-963.

11. Gómez-Sáez, J. M., M. Fernández Castañer, M. A. Navarro, M. R. Bonnin, J. Soler Ramón, and A. Roca. 1981. Resistencia parcial a las hormonas tiroideas con bocio y eutiroidismo. Med. Clin. 76:412-416.

12. Eil, C., H. G. Fein, T. J. Smith, R. W. Furlanetto, M. Bourgeois, M. W. Stelling, and B. D. Weintraub. 1982. Nuclear binding of $\left[{ }^{125} I\right]$ triiodothyronine in dispersed cultured skin fibroblasts from patients with resistance to thyroid hormone. J. Clin. Endocrinol. \& Metab. 55:502-510.

13. Sap, J., A. Munoz, K. Damm, Y. Goldberg, J. Ghysdael, A. Lenz, H. Beng, and B. Vennstrom. 1986. The c-erb-A protein is a high-affinity receptor for thyroid hormone. Nature (Lond.). 324:635-640.

14. Weinberger, C., C. C. Thompson, E. S. Ong, R. Lebo, D. J. Gruol, and R. M. Evans. 1986. The c-erb-A gene encodes a thyroid hormone receptor. $\mathrm{Na}$ ture (Lond.). 324:641-646.

15. Koenig, R. J., R. L. Warne, G. A. Brent, J. W. Harney, P. R. Larsen, and D. D. Moore. 1988. Isolation of a cDNA clone encoding a biologically active thyroid hormone receptor. Proc. Natl. Acad. Sci. USA. 85:5031-5035.

16. Damm, K., C. C. Thompson, and R. M. Evans. 1989. Protein encoded by v-erbA functions as a thyroid-hormone receptor antagonist. Nature (Lond.). 339:593-597.

17. Benbrook, D., and M. Pfahl. 1987. A novel thyroid hormone receptor encoded by a cDNA clone from a human testis library. Science (Wash. DC). 238:788-791.

18. Nakai, A., A. Sakurai, G. I. Bell, and L. J. DeGroot. 1988. Characterization of a third human thyroid hormone receptor coexpressed with other thyroid hormone receptors in several tissues. Mol. Endocrinol. 2:1087-1092.

19. Dayton, A. I., J. R. Selden, G. Laws, D. J. Dorney, J. Finan, P. Tripputi, B. S. Emanuel, G. Rovera, P. C. Novell, and C. M. Croce. 1984. A human c-erbA oncogene homologue is closely proximal to the chromosome 17 breakpoint in acute promyelocytic leukemia. Proc. Natl. Acad. Sci. USA. 81:4495-4499.

20. Hodin, R. A., M. A. Lazar, B. I. Wintman, D. S. Darling, R. J. Koenig, P. R. Larsen, D. D. Moore, and W. W. Chin. 1989. Identification of a thyroid hormone receptor that is pituitary-specific. Science (Wash. DC). 244:76-79.

21. Mitsuhashi, T., G. E. Tennyson, and V. M. Nikodem. 1988. Alternative splicing generates messages encoding rat c-erbA proteins that do not bind thyroid hormones. Proc. Natl. Acad. Sci. USA. 85:5804-5805.

22. Evans, R. M. 1988 . The steroid and thyroid hormone receptor superfamily. Science (Wash. DC). 240:889-895.

23. Sakurai, A., K. Takeda, K. Ain, P. Ceccarelli, A. Nakai, S. Seino, G. I. Bell, S. Refetoff, and L. J. DeGroot. 1989. Generalized resistance to thyroid hormone associated with a mutation in the ligand-binding domain of the human thyroid hormone receptor $\beta$. Proc. Natl. Acad. Sci. USA. 86:8977-8981.

24. Usala, S. J., G. E. Tennyson, A. E. Bale, R. W. Lash, N. Gesundheit, F. E. Wondisford, D. Accili, P. Hauser, and B. D. Weintraub. 1990. A base mutation of the c-erbA $\beta$ thyroid hormone receptor in a kindred with generalized thyroid hormone resistance. Molecular heterogeneity in two other kindreds. J. Clin. Invest. 85:93-100.

25. Sakurai, A. A. Nakai, and L. J. DeGroot. 1990. Structural analysis of human thyroid hormone receptor $\beta$ gene. Mol. Cell. Endocrinol. 71:83-91.

26. Nichols, W. C., J. J. Liepnieks, V. A. McKusick, and M. D. Benson. 1989. Direct sequencing of the gene for Maryland/German familial amyloidotic polyneuropathy type II and genotyping by allele-specific enzymatic amplification. Genomics. 5:535-540.

27. Newton, C. R. A. Graham, L. E. Heptinstall, S. J. Powell, C. Summers, N. Kalsheker, J. C. Smith; and A. F. Markham. 1989. Analysis of any point mutation in DNA. The amplification refractory mutation system (ARMS). Nucleic Acids Res. 17:2503-2516.

28. Ceccarelli, P., S. Refetoff, and Y. Murata. 1987. Resistance to thyroid hormone diagnosed by the reduced response of fibroblasts to the triiodothyronine induced suppression of fibronectin synthesis. J. Clin. Endocrinol. \& Metab. 65:242-246.

29. Usala, S. J., A. E. Bale, N. Gesundheit, C. Weinberger, R. W. Lash, F. E. Wondisford, O. W. McBride, and B. D. Weintraub. 1988. Tight linkage between the syndrome of generalized thyroid hormone resistance and the human c-erbA $\beta$ gene. Mol. Endocrinol. 2:1217-1220.

30. Refetoff, S., R. Matalon, and M. Bigazzi. 1972. Metabolism of L-thyroxine (T4) and L-triiodothyronine (T3) by human fibroblasts in tissue culture: evidence for cellular binding proteins and conversion of T4 to T3. Endocrinology. 91:934947.

31. Murata, Y., S. Refetoff, A. L. Horwitz, and T. J. Smith. 1983. Hormonal regulation of glycosaminoglycan accumulation in fibroblasts from patients with resistance to thyroid hormone. J. Clin. Endocrinol. \& Metab. 57:1233-1239.
32. Bernal, J., S. Refetoff, and L. J. DeGroot. 1978. Abnormalities of triiodothyronine binding to lymphocyte and fibroblast nuclei from a patient with peripheral resistance to thyroid hormone action. $J$. Clin. Endocrinol \& Metab. 47:1266-1272.

33. Refetoff, S., L. J. DeGroot, and C. P. Barsano. 1980. Defective thyroid hormone feedback regulation in the syndrome of peripheral resistance to thyroid hormone. J. Clin. Endocrinol. \& Metab. 51:41-45.

34. Pagliara, A. S., R. H. Caplan, C. B. Gundersen, G. G. Wickus, and A. C. V. Elston III. 1983. Peripheral resistance to thyroid hormone in a family: heterogeneity of clinical presentation. J. Pediatr. 103:228-232.

35. Daubresse, J. C., B. Dozin-Van Roye, P. DeNayer, and M. DeVisscher. 1980. Partial resistance to thyroid hormones: reduced affinity of lymphocyte nuclear receptors for T3 in two siblings. In Thyroid Research, Proceedings of the VI International Thyroid Congress, Melbourne, Australia. J. R. Stockigt and S. Nagataki, editors. Australian Academy of Science/Canberra. 295-298.

36. Chait, A., R. Kanter, W. Green, and M. Kenny. 1982. Defective thyroid hormone action in fibroblasts cultured from subjects with the syndrome of resistance to thyroid hormones. J. Clin. Endocrinol. \& Metab. 54:767-772.

37. Refetoff, S., A. Salazar, T. J. Smith, and N. H. Scherberg. 1983. The consequences of inappropriate treatment due to failure to recognize the syndrome of pituitary and peripheral tissue resistance to thyroid hormone. Metab. Clin. Exp. 32:822-834.

38. Wortsman, J., B. N. Premachandra, K. Williams, K. D. Burman, I. D. Hay, and P. J. Davis. 1983. Familial resistance to thyroid hormone associated with decreased transport across the plasma membrane. Ann. Intern. Med. 98:904-909.

39. Hughes, I. A., K. Ichikawa, L. J. DeGroot, R. John, M. K. Jones, R. Hall, and M. F. Scanlon. 1987. Non-adenomatous inappropriate TSH hypersecretion and euthyroidism requires no treatment. Clin. Endocrinol. 27:475-483.

40. Ichikawa, K., I. A. Hughes, A. L. Horwitz, and L. J. DeGroot. 1987. Characterization of nuclear thyroid hormone receptors of cultured skin fibroblasts from patients with resistance to thyroid hormone. Metab. Clin. Exp. 36:392-399.

41. Bell, G. I., J. H. Karam, and W. J. Rutter. 1981. Polymorphic DNA region adjacent to the $5^{\prime}$ end of the human insulin gene. Proc. Natl. Acad. Sci. USA. 78:5759-5763.

42. Saiki, R. K., D. H. Gelfand, S. Stoffel, S. J. Scharf, R. Higuchi, G. T. Horn, K. B. Mullis, and H. A. Erlich. 1988. Primer-directed enzymatic amplification of DNA with thermostable DNA polymerase. Science (Wash. DC). 239:481-491.

43. Mori, Y., S. Refetoff, I. L. Flink, M. Charbonneau, Y. Murata, H. Seo, E. Morkin, and J. H. Dussault. 1988. Detection of thyroxine-binding globulin (TBG) gene in six unrelated families with complete TBG deficiency. J. Clin. Endocrinol. \& Metab. 67:727-733.

44. Antonarakis, S. E., and H. H. Kazazian, Jr. 1988. The molecular basis of hemophilia A. Trends Genet. 4:233-237.

45. Theophilus, B. D. M., T. Latham, G. A. Grabowski, and F. I. Smith. 1989. Comparison of RNase A, a chemical cleavage and GC-clamped denaturing gradient gel electrophoresis for the detection of mutations in exon 9 of the human acid $\beta$-glucosidase gene. Nucleic Acids Res. 17:7707-7722.

46. Weiss, R. E., S. Balzano, N. Scherberg, and S. Refetoff. 1990. Neonatal detection of generalized resistance to thyroid hormone. JAMA (J.Am. Med. Assoc.). 264: 2245-2250.

47. Sakurai, A., A. Nakai, and L. J. DeGroot. 1989. Expression of three forms of thyroid hormone receptor in human tissues. Mol. Endocrinol. 3:392-399.

48. Hodin, R. A., M. A. Lazar, and W. W. Chin. 1990. Differential and tissue-specific regulation of the multiple rat c-erbA messenger RNA species by thyroid hormone. J. Clin. Invest. 85:101-105.

49. Ridgway, E. C., I. A. Kourides, W. W. Chin, D. S. Cooper, and F. Maloof. 1979. Augmentation of pituitary thyrotrophin response to thyrotrophin releasing hormone during subphysiological tri-iodothyronine therapy in hypothyroidism. Clin. Endocrinol. 10:343-353.

50. Schueler, P. A., H. L. Schwartz, K. A. Strait, C. N. Mariash, and J. H. Oppenheimer. 1990. Binding of 3,5,3'-triiodothyronine (T3) and its analogs to the in vitro translational products of c-erbA protooncogenes: differences in the affinity of $\alpha$-and $\beta$-forms for the acetic acid analog and failure of the human testis and kidney $\alpha-2$ products to bind T3. Mol. Endocrinol. 4:227-234.

51. Oppenheimer, J. H., P. Coulombe, H. L. Schwartz, and N. W. Gutfeld. 1978. Nonlinear (amplified) relationship between nuclear occupancy by triiodothyronine and the appearance rate of hepatic $\alpha$-glycerophosphate dehydrogenase and malic enzyme in the rat. J. Clin. Invest. 61:987-997.

52. Brent, G. A., J. W. Harvey, Y. Chen, R. L. Warne, D. D. Moore, and P. R. Larsen. 1989. Mutations of the rat growth hormone promoter which increase and decrease response to thyroid hormone define a consensus thyroid hormone response element. Mol. Endocrinol. 3:1996-2004.

53. Glass, C. K., S. M. Lipkin, O. V. Devary, and M. G. Rosenfeld. 1989. Positive and negative regulation of gene transcription by a retinoic acid-thyroid hormone receptor heterodimer. Cell. 59:697-708. 